\title{
Antimicrobial Susceptibility and Resistance Pattern of Mastitis Milk Samples from Chittoor District, Andhra Pradesh, India
}

\author{
D. Rani Prameela ${ }^{1 *}$, D. Sreenivasulu ${ }^{2}$, N. Mangadevi ${ }^{1}$ and A. Karthik ${ }^{1}$ \\ ${ }^{1}$ State Level Diagnostic Laboratory, Sri Venkateswara Veterinary University, \\ Tirupati-517502, Chittoor District, Andhra Pradesh, India \\ ${ }^{2}$ Director of Extension, SVVU, Tirupati, India \\ *Corresponding author
}

\section{A B S T R A C T}

\begin{abstract}
Mastitis has been a major problem to the dairy industry and pose main impact on the economy of dairy farmers. Antibiotic resistance is increasing day by day and has become a big challenge worldwide with public health significance. In the present study antimicrobial resistance and sensitivity pattern of mastitis milk samples were assessed during the period from August, 2015 to March, 2020 at State level diagnostic laboratory, Sri Venkateswara Veterinary University, Tirupati. A total of 2,488 milk samples were subjected for cultural isolation and invitro antibiotic sensitivity test with standard disc diffusion method (Bauer et al., 1966). Out of 2,488 milk samples on cultural isolation, 2,174 (87.38\%) of gram positive and $314(12.62 \%)$ of gram negative bacteria were identified. Among 2,174 gram positive bacteria, Staphylococcus aureus $-2,133(98.11 \%)$ was predominant followed by Streptococci-20 (0.92\%) and bacillus species $-19(0.87 \%)$. Similarly, among 314 gram negative bacteria, E.coli-255(81.20\%) were major pathogens followed by Klebsiella-53 (16.88\%) and Pseudomonas $-14(4.46 \%)$ were identified. Invitro, antibiotic sensitivity test results of gram positive bacterial isolates $(2,174)$ showed resistance and sensitivity to Amikacin $(90.4 \% ; 9.60 \%)$ followed by Kanamycin $(88.4 \% ; 11.6 \%)$, Streptomycin $(87.5 \%$; $12.50 \%)$, Tetracycline $(79.6 ; 20.4 \%)$, Gentamycin $(75.3 \% ; 24.7 \%)$, Pencillin $(60.2 \%$; $39.8 \%)$, Ciprofloxacin (52.50 ; 45.7\%), Enrofloxacin (48.9\%; 51.20), Ampicillin $(45.1 \% ; 54.9 \%)$ and Amoxycillin $(36.4 \% ; 63.6 \%)$ respectively. Whereas the isolates of gram negative bacteria revealed resistance and sensitivity to Kanamycin-78.71\%; $21.30 \%$ followed by Pencillin-76.81\%; 23.10\%, amikacin-69.11\%; 30.90\%), Tetracyclin (66.61\% ; $33.40 \%)$, Streptomycin-(66.6\%;33.40\%), Ampicillin $(64.70 \% ; 35.40)$, Gentamycin $(51.0 \%$; $49.0 \%)$, Ciprofloxacin $(42.0 \% ; 58.0 \%)$ and Enrofloxacin-(34.71\%;65.30\%) $(109 / 314)$.
\end{abstract}

\section{Introduction}

Mastitis is the most common and most economically significant disease affecting dairy cattle. It is the leading cause of antimicrobial use on dairy farms (Saini et al.,
2012). Dairy farming is major livelihood of rural farmers in Andhra Pradesh and facing great problem of incidence of mastitis in diary animals. A variety of bacteria can be isolated from bovine mastitis cases. Staphylococcus aureus and Escherichia coli are the most 
common causes of contagious and environmental clinical as well as subclinical mastitis cases respectively (Barkema et al., 1988). Mastitis adversely affects animal health, quality of milk and milk production affecting economy of the developed and developing countries causing huge economic losses (Sharma et al., 2007). The main line of treatment of mastitis is the use of antibiotics as intramuscular infections or intra mammary infections (Kalmus et al., (2014). In majority cases, treatment failure and recurrence of mastitis is due to indiscriminate use of antibiotics without testing for invitro sensitivity of causative organisms (Koch et al., 2013). This practice not only causes economic losses to dairy farmers but also leads to antimicrobial resistance in animals and consequently affecting humans and as a source of food borne pathogen. Despite the best possible antimicrobial treatments, failures of bacteriological common, especially for Staphylococcus aureus mastitis, and antimicrobial resistance (AMR) is considered as one of the reasons for low cure rates (Barkema et al., (2006). Multi-drug resistant bacteria are a persistent problem in modern healthcare, food safety and animal health. Therefore, present work was undertaken to study the antibiotic sensitivity and resistance pattern of common pathogens of mastitis cases in milch animals of Andhra Pradesh for therapeutic measure in control of mastitis.

\section{Materials and Methods}

\section{Milk samples}

A total of 2,488 Milk samples were collected aseptically and randomly from organized and unorganized sectors of milch animals in Chittoor District of Andhra Pradesh during the period from August, 2015 to March, 2020. Milk samples were collected in $10 \mathrm{ml}$ sterile tubes with strict aseptic precautions. The udder was washed with $1 \%$ potassium permanganate solution and wiped with clean dry cloth or tissue paper. Teats and hands were disinfected with 70 percent alcohol and first few strippings's were discarded and finally last milk was collected into sterile tubes and transported immediately to laboratory on ice.

\section{Culturing}

The collected milk samples were inoculated into nutrient broth and streaked on to selective medium. Mannitol salt agar media, Edward's media, Eosine Methylene blue agar media and selective differential media of blood agar and macconkey's agar media to obtain pure cultures.

\section{Identification of bacteria}

Isolated cultures were identified by grams staining as per the method of Cruick shank et al., (1970).

\section{Bio-chemical confirmation}

Cultural isolates were confirmed with biochemical test, catalase test, coagulase test, oxidase test, indole test, methyl red test, voges proskauer test and citrate test as per the protocols mentioned in the text book of Clinical Veterinary Microbiology by Markey et al., 2013; Quin and Carter.

\section{In-vitro antibiotic sensitivity test for bacterial isolates}

All the isolated bacterial cultures $(2,488)$ were subjected to antibiotic sensitivity test by standard disc diffusion technique as per the method of Bauer et al, 1966 using Muller Hinton agar media. The antibiotics discs were procured from Hi-Media laboratories private limited, Bombay, India. The sensitivity and resistance patterns were recorded with the zone of inhibition and compared with zone 
size interpretative chart furnished by the manufacturer of the antibiotics (Hi-media).

\section{Results and Discussion}

A total of 2,488 milk samples were collected and processed for culturing as well as invitro susceptibility test to assess the pattern of antimicrobial susceptibility and resistance from Chittoor District, Andhra Pradesh during the period from August, 2015 to March, 2020 at State Level Diagnostic Laboratory, Tirupati. Out of 2,488 milk samples subjected for cultural isolation, $2,174(87.38 \%)$ were of Gram positive and $314(12.62 \%)$ of gram negative pathogens were identified. Among 2,174 gram positive bacterial pathogens, S.aureus -2,131(98.02\%) was found to be more predominant bacteria followed by Streptococcus-20 (0.92\%) and Bacillus species-20 (0.92\%) (Table.1). Similarly, among 314 gram negative bacteria, E.coli-255 (81.20\%) followed by Klebseilla-53 (16.88\%) and Pseudomonas-14 (4.46\%). However, out of 2,488 milk samples, 3 samples $(0.14 \%)$ were found positive for Candida (Table.1).

During the period of work, invitro antibiotic sensitivity test results of gram positive bacterial isolates showed resistance to Amikacin -90.43\% (1966/2174) followed by Kanamycin -88.36\% (1921/2174), Streptomycin-87.49\% (1902/2174), Tetracycline$79.62 \% \quad(1731 / 2174), \quad$ Gentamycin-75.30\% (1637/2174), Pencillin-60.17\% (1308/2174), Ciprofloxacin-52.48\% (1141/2174), Enrofloxacin-48.80\% (1061/2174), Ampicillin-45.08\% (980/2174) and Amoxycillin-36.43\% (792/2174) (Table.2 \& Fig.1).

Similarly, antibiotic sensitivity pattern of gram positive bacterial isolates include higher sensitivity to Amoxycillin $-63.57 \%$ (792/2174) followed by Ampicillin-54.92\% (980/2174), Enrofloxacin-51.20\% (1061/ 2174), Ciprofloxacin-47.52\% (1141/2174),
Pencillin-39.83\% (1308/ 2174), Gentamycin$24.70 \%$ (1637/2174), Tetracycline-20.38\% (1731/2174), Streptomycin-12.51\% (1902/ 2174), Kanamycin-11.64\% (1921/2174) and Amikacin -9.57\% (1966/2174) (Table-3 \& Fig.2).

Whereas, gram negative bacterial isolates (314) revealed resistance to Kanamycin$78.66 \%$ (247/314) followed by Pencillin$76.75 \% \quad$ (241/314), Amikacin-69.11\% (217/314), Tetracyclin66.56\% (209/314), Streptomycin-66.56\% (209/314), ampicillin64.65 (203/314), Gentamycin50.96\% (160/ 314), Amoxycillin-45.22\% (142/314), Ciprofloxacin-42.04\% (132/314) and enrofloxacin-34.71\% (109/314) (Table-3 \& fig.3) respectively.

But, gram negative bacterial isolates showed high sensitivity to enrofloxacin-65.20\% (109/314), Ciprofloxacin-57.96\% (132/314), Amoxycillin $-54.78 \%$ (142/314), Gentamycin $-49.04 \%$ (160/314), Ampicillin-35.35\% (203/314), Streptomycin-33.44\% (209/314), Tetracycline $-33.44 \%$ (209/314), Amikacin $30.89 \% \quad$ (217/314), Pencillin-23.25\% (241/314) and Kanamycin -21.34\% (247/314) respectively (Table. 3 \& Fig.4) respectively.

During the study out of 2,488 milk samples, $2,174(87.37 \%)$ gram positive bacteria and $314(12.62 \%)$ gram negative bacteria were recorded on cultural isolation. But earlier Nesser et al., 2006 reported higher 93\% of gram positive bacteria and $30 \%$ of gram positive bacteria.

Whereas Keffe et al., (2011) recorded 55\% of gram positive and $11 \%$ of gram negative bacteria. Staphylococcus aureus is an important cause of contagious mastitis responsible for udder infections in dairy herds. 
Table.1 Prevalence of various bacterial pathogens isolated from bovine clinical mastitis

\begin{tabular}{|c|c|c|c|c|c|c|c|c|c|c|c|}
\hline \multirow[t]{2}{*}{ S.No. } & \multirow[t]{2}{*}{ Year } & \multirow{2}{*}{$\begin{array}{c}\text { Total milk } \\
\text { samples } \\
\text { screened/testes }\end{array}$} & \multicolumn{4}{|c|}{ Gram positive organisms } & \multirow{2}{*}{$\begin{array}{c}\text { Fungi } \\
\text { Candida }\end{array}$} & \multicolumn{4}{|c|}{ Gram negative organisms } \\
\hline & & & S.aureus & $\begin{array}{l}\text { Strepto } \\
\text { coccus }\end{array}$ & Bacillus & Total & & E.coli & Klebseilla & Pseudomonas & Total \\
\hline 1. & $2015-16$ & 320 & 272 & 6 & - & 278 & - & 32 & 8 & 2 & 42 \\
\hline 2. & 2016-17 & 480 & 408 & 6 & 3 & 417 & - & 52 & 7 & 4 & 63 \\
\hline 3. & 2017-18 & 460 & 393 & 3 & 5 & 401 & - & 46 & 10 & 3 & 59 \\
\hline 4. & 2018-19 & 650 & 557 & 2 & 4 & 565 & 2 & 71 & 12 & 2 & 85 \\
\hline 5. & 2019-20 & 578 & 501 & 3 & 8 & 513 & 1 & 54 & 8 & 3 & 65 \\
\hline \multicolumn{2}{|c|}{ Grand total } & 2,488 & 2,131 & 20 & 20 & 2,174 & 3 & 255 & 53 & 14 & 314 \\
\hline & & $\%$ Positivity & 98.02 & 0.92 & 0.92 & 87.37 & 0.14 & 81.20 & 16.88 & 4.46 & 12.62 \\
\hline
\end{tabular}

Table.2 Pattern of Antibiotic Resistance and Sensitivity against gram positive bacteria

\begin{tabular}{|c|c|c|c|c|c|}
\hline S.no & Antibiotic & \multicolumn{4}{|c|}{ Gram positive bacteria (n=2,174) } \\
\cline { 3 - 6 } & & $\begin{array}{c}\text { No. } \\
\text { Resistant }\end{array}$ & \% Resistance & $\begin{array}{c}\text { No. } \\
\text { Sensitive }\end{array}$ & \% Sensitivity \\
\hline 1. & Amikacin & 1966 & 90.43 & 208 & 9.57 \\
\hline $\mathbf{2 .}$ & Kanamycin & 1921 & 88.36 & 253 & 11.64 \\
\hline 3. & Streptomycin & 1902 & 87.49 & 272 & 12.51 \\
\hline $\mathbf{4 .}$ & Tetracyclin & 1731 & 79.62 & 443 & 20.38 \\
\hline $\mathbf{5 .}$ & Gentamycin & 1637 & 75.30 & 537 & 24.70 \\
\hline $\mathbf{6 .}$ & Pencillin & 1308 & 60.17 & 866 & 39.83 \\
\hline $\mathbf{7 .}$ & Ciprofloxacin & 1141 & 52.48 & 1033 & 47.52 \\
\hline $\mathbf{8 .}$ & Enrofloxacin & 1061 & 48.80 & 1131 & 51.20 \\
\hline 9. & Ampicillin & 980 & 45.08 & 1194 & 54.92 \\
\hline $\mathbf{1 0 .}$ & Amoxycillin & 792 & 36.43 & 1382 & 63.57 \\
\hline
\end{tabular}


Table.3 Pattern of Resistance and Sensitivity against gram Negative bacteria

\begin{tabular}{|l|c|c|c|c|c|}
\hline \multirow{2}{*}{ S.no. } & Antibiotic & \multicolumn{4}{|c|}{ Gram Negative bacteria (n=314) } \\
\cline { 3 - 6 } & & No. Resistant & \% Resistance & No. Sensitive & \% Sensitivity \\
\hline 1. & Kanamycin & 247 & 78.66 & 67 & 21.34 \\
\hline $\mathbf{2 .}$ & Pencillin & 241 & 76.75 & 73 & 23.25 \\
\hline $\mathbf{3 .}$ & Amikacin & 217 & 69.11 & 97 & 30.89 \\
\hline $\mathbf{4 .}$ & Tetracycline & 209 & 66.56 & 105 & 33.44 \\
\hline $\mathbf{5 .}$ & Streptomycin & 209 & 66.56 & 105 & 33.44 \\
\hline 6. & Ampicillin & 203 & 64.65 & 111 & 35.35 \\
\hline 7. & Gentamycin & 160 & 50.96 & 154 & 49.04 \\
\hline 8. & Amoxycillin & 142 & 45.22 & 172 & 54.78 \\
\hline 9. & Ciprofloxacin & 132 & 42.04 & 182 & 57.96 \\
\hline $\mathbf{1 0 .}$ & Enrofloxacin & 109 & 34.70 & 205 & 65.29 \\
\hline
\end{tabular}

Fig.1 Antibiotic resistance pattern of gram positive bacteria

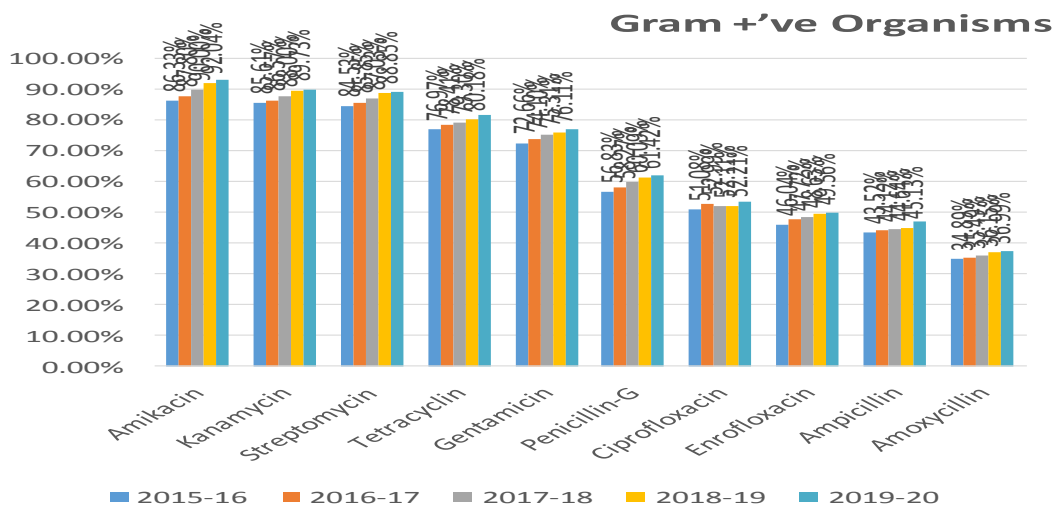

Fig.2 Antibiotic Sensitivity pattern of Gram Positive bacteria from 2015-16 to 2019-20

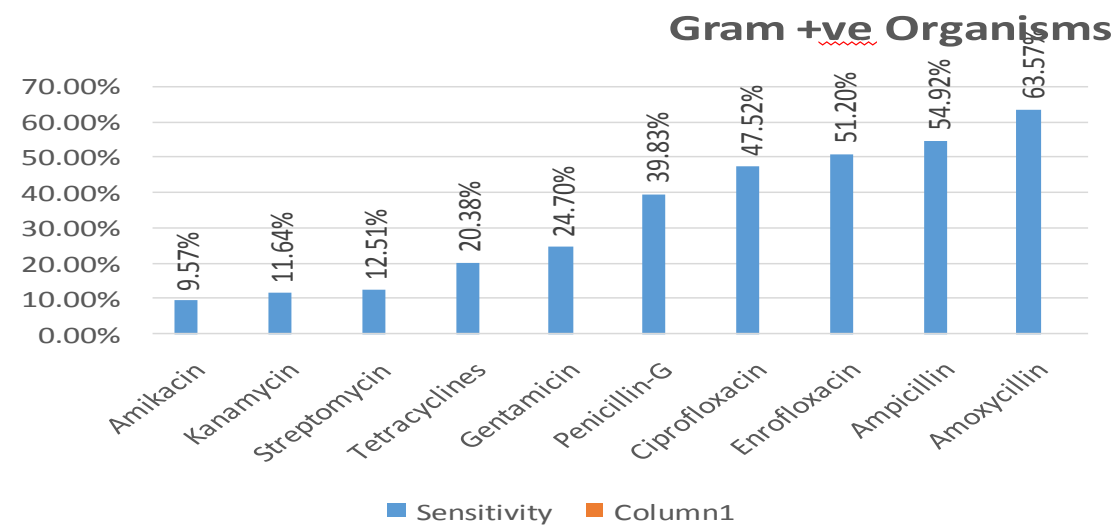


Fig.3 Antibiotic Resistance pattern of gram negative bacteria

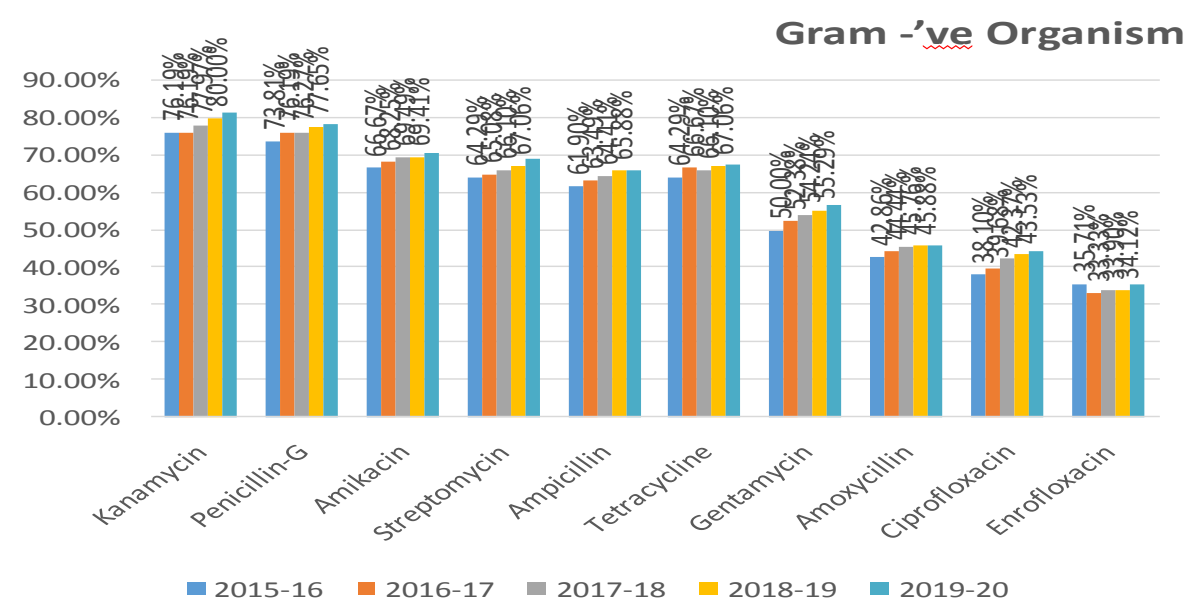

Fig.4 Antibiotic Sensitivity pattern of Gram negative bacteria from 2015- 16 to 2019-20

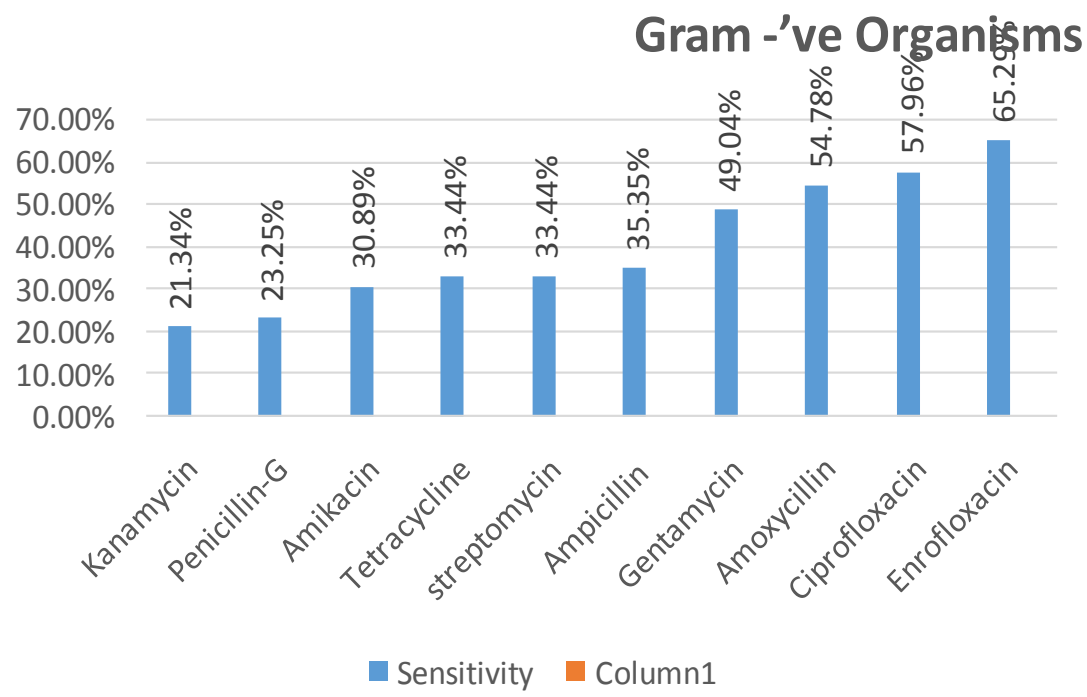

Staphylococcal species was the major pathogen causing mastitis with high incidence was reported during the study. Previously, similar reports were recorded by several workers from different parts of the country. (Sumathi et al., (2008); Das and Joseph (2005); Sharma and Sindhu (2007); Bhanot et al (2012); Hawari and Dabas (2008); Tenhagen et al., (2009); Nickerson (2009) and Zutic et al., (2012) etc. In the present study, among gram positive bacteria cultural isolation yielded $(98.11 \%$ of Staphylococcus aureus as major causative gram positive bacteria followed by Streptococcus (0.92\%) and bacillus species with $0.87 \%$.

The higher incidence of staphylococcus during the study indicated the unhygienic 
milking hands and practices as Staphylococcus mainly spread during milking via milkers hands Bradley (2002).Further, this might also be due to harbouring of Staphylococci on the skin of the udder, teat which acts as reservoir for the infection (Spencer and Lasmanis (1952); Davidson (1961). Distribution of mastitis pathogens changes overtime, therefore, bacteriological examination at herd level must be taken regularly to monitor udder health.

Antibiotic sensitivity profile will be helpful to recommend early therapy at the field level prior to availability of results of cultural isolation. During the study, gram positive bacteria showed higher resistance to Amikacin (90.43\%) followed by Kanamycin $(88.36 \%)$ and Streptomycin $(87.49 \%)$ but showed high sensitivity to Amoxycillin (63.57\%) followed by Ampicillin (54.92\%) and Enrofloxacin (51.20\%) respectively. Higher resistance to Amikacin followed by Kanamycin and streptomycin might be due to indiscriminate usage of these antibiotics in majority of the Districts of Andhra Pradesh in treating mastitis cases. This was in accordance with previous reports of Qayyum et al., 2016; Hussain et al and Idriss et al., 2014.

Among gram negative bacteria, E.coli was the major pathogen isolated (81.21) followed by Klebsiella (16.88\%) and Pseudomonas $(4.46 \%)$ and it could be due to damp environmental conditions in the dairy herds. Among gram negative bacteria, the prevalence of E.coli was indicator of poor hygienic practices in dairy environment, as these organisms originate from the cow's environment and infect the udder through teat canal. Contamination of end of the teat is a major predisposing factor in the development of environmental mastitis (Bradley, 2002.)

In the Current study, gram negative bacteria showed higher resistance to Kanamycin, Pencillin, Amikacin, Streptomycin and Tetracylclins and high sensitivity to Enrofloxacin followed by Ciprofloxacin, Amoxycillin and Gentamycin respectively. Almost similar findings were reported by Chauhan et al., (2016) \& Arthanari Eswaran et al., (2018) except Amoxycillin.

The mastitis bacteria showed less sensitivity to the commonly used antibiotics, due to the frequent use of the particular antibiotics in that particular geographical locations. Indiscriminate and frequent use of these antibiotics in animals could be the reason for their in-effectiveness against mastitis bacteria (Harshit Verma et al., 2018).

Antimicrobial resistance represents a serious problem in the treatment of infectious diseases including mastitis. In recent times, an increasing antimicrobial resistance rate has been recognized in Staphylococcus aureus from bovine mastitis (Saini et al., 2012; Wang et al., 2013.). Due to antimicrobial usage over many decades, multiple drug resistance among the mastitis causing agents is a major problem in controlling intra-mammary infections. This is generally attributed to indiscriminate and continuous use of antibacterial drugs without prior drug susceptibility testing or selection pressure of antimicrobials on pathogens or colonization of the mammary gland by resistant strains. Such antimicrobial resistant organisms can pose serious health related problems to animals as well as human beings.

In conclusion, the present work represents the data pertaining to the prevalence of mastitis causing pathogens of bacterial origin and the assessment of resistance as well as sensitivity of various antimicrobials used against mastitis of the different Districts (Geographical areas) of Andhra Pradesh. Gram positive organisms playing important role compared to the gram 
negative bacteria in causing mastitis. Among gram positive bacteria staphylococcus aureus was the predominant pathogen followed by streptococcus and bacillus species where as among gram negative bacteria, E.coli was the predominant pathogen followed by Klebsiella and Pseudomonas species. Gram positive bacteria showed higher resistance to Amikacin $(90.43 \%)$ followed by Kanamycin $(88.41 \%)$ and streptomycin $(87.49 \%)$ but amoxycillin (63.57\%) followed by Ampicillin $(54.90 \%)$ and Enrofloxacin $(51.20 \%)$ showed higher sensitivity. Similarly, gram negative bacteria showed resistant to Kanamycin (78.66\%) followed by Pencillin $(76.81 \%)$ and Amikacin (69.10\%) and Tetracylcin (66.60\%) and higher sensitivity to Enrofloxacin $(65.29 \%)$ followed by ciprofloxacin $(57.46 \%)$ and Amoxycillin (54.88\%) etc was observed. However, epidemiological surveillance and regular conduct of antibiotic sensitivity tests are of important to avoid antimicrobial resistance, as antibiotic therapy is playing major role in control of mastitis in milch animals to serve the farmers and to increase the socio economic status of the farmers.

\section{Acknowledgments}

The authors are highly thankful to Honorable Vice-Chancellor and Director of Research of Sri Venkateswara Veterinary University, Tirupati Andhra Pradesh in providing necessary facilities/funding to carry out this work.

\section{References}

Arthanari. E.M., Vadivoo VS, Hariharan T and Sukumar, K. 2018. Bovine clinical mastitis and antibiotic resistance pattern in Tirupur District. Pharma Innovation. 7(11): 391393.

Barkema, H. W., Y. H. Schukken, and R. N. Zadoks. 2006. Invited review: The role of cow, pathogen, and treatment regimen in the therapeutic success of bovine
Staphylococcus aureus mastitis. J. Dairy Sci. 89:1877-1895.

Barkema, H. W., Y. H. Schukken, T. J. G. M. Lam, M. L. Beiboer, H.1988. Wilmink, G. Benedictus, and A. Brand. 1998. Incidence of clinical mastitis in dairy herds grouped in three categories by bulk milk somatic cell counts. J. Dairy Sci. 81:411-419.

Bauer, A.W., Kirby, W.M.M., Sherris, J.C., and Turck,M. 1966. Antibiotic susceptibility testing by a standardized single disc method. American Journal of Clini.Path. 45:493-496.

Bhanot V, Chaudhri SS, Bisla RS, Singh H. 2012. Retrospective study on prevalence and antibiogram of mastitis in cows and buffaloes of Eastern Haryana. Indian J. Anim. Res. 46(2):160-163.

Bradley AJ.2002. Bovine mastitis an evolving disease. The Veterinary Journal. 164:116128.

Chauhan, P.M., Thumar HK, Bhagat A, Sharma VK, Chauhan HC, Patel MR. 2016. Comparative efficacy of antibiotic sensitivity tests for management of acute clinical Escherichia coli mastitis in crossbred cow. J Livest. Sci. 7:41-45.

Das, P.K. and Joseph, E. 2005. Identification and antibiogram of Microbes associated with buffalo mastitis in Jabalpur, Madhya Pradesh, India. Buffalo Bulletin, 24 (1): 39.

Davidson, I. 1961. Observation on pathogenic Staphylococci in dairy herd during a period of six years. Res. Vet. Sci. 2:22.

Harshit Verma, Shriya Rawat, Nishant Sharma, Vikas Jaiswal and Rajeev Singh. 2018. Prevalence, bacterial etiology and antibiotic susceptibility pattern of bovine mastitis in Meerut. J. Entomol. Zool. Stud. 6(1):706-709.

Hawari, A.D. and F. Al-Dabbas, 2008. Prevalence and distribution of mastitis pathogens and their resistance against antimicrobial agents in dairy cows in Jordan. Am. J. Anim. Vet. Sci., 3: 36-39.

Hussain, R., A.Khan, M.T. Javed and F. Rizvi. 2012. Possible risk factors associated with mastitis in indigenous cattle in Punjab, Pakistan. Pak. Vet. J.32:605-608.

Idriss, S.E., V.Foltys, V. Tancin, K. Kirchnerova, 
D. Tancinova and K. Zaujec. 2014. Mastitis pathogens and their resistance against antimicrobial agents in dairy cows in Nitra, Slovakia, Slovak J. Anim. Sci.47:33-38.

Kalmus P, Simojoki H, Orro T, Taponen S, Mustonen K, Holopainen J, et al., 2014. Efficacy of 5-day parenteral versus intramammary benzyl penicillin for treatment of clinical mastitis caused by gram-positive bacteria susceptible to penicillin in vitro. J. Dairy Sci. 97: 21552164.

Keefe, G., McCarron.Jennifer., MacDonald. Kimberley and Cameron. Marguerite. 2011. Using on-Farm mastitis culturing. WCDS Advances in Dairy Technology Volume 23: 81-91.

Koch R, Schaumburg F, Mellmann A, Jurke A, Becker K, Friedrich AW. 2013. LivestockAssociated methicillin resistant Staphylococcus aureus (MRSA) as causes human infection and colonization in Germany. PLoS One. 8(2):e55040.

Markey, B.K., Leonard, F.C., Archambault, M., Cullinane, A., and Maguire, D.2013. Text book of Clinical Veterinary Microbiology, 2nd edition.Elsevier

Neeser, N.L., W.D. Hueston, S.M. Godden, and R.F. Bey. 2006. Evaluation of the use of an on-farm system for bacteriologic culture of milk from cows with low-grade mastitis. $J$ Am Vet Med. Assoc. 228:254-260.

Nickerson, S.C. 2009. Control of Heifer Mastitis: Antimicrobial treatment-an overview. Vet Microbiol. 134:128-135.

Qayyum, A., Khan, J.A., Hussain, R., Khan,A., Avais,M.,Ahmad, $\mathrm{N}$ and Hassan, M.F. 2016. Molecular characterization of staphylococcus aureus isolates recovered from natural cases of subclinical mastitis in Holstein cattle and their antibacterial susceptibility. Pak.J.Agri.Sci., Vol. 53(4).

Saini, V., J. T. McClure, D. Leger, G.P.Keefe., Sheldon, D. T., Scholl, Morck. D.W and H. W. Barkema. 2012. Antimicrobial resistant profiles of common mastitis pathogens on Canadian dairy farms. J. Dairy Sci. 95: 4319-4332.

Sharma A, Sindhu N. 2007. Occurrence of clinical and subclinical mastitis in buffaloes in the State of Haryana (India). Ital. J. Anim. Sci. 6(2):965-967.

Spencer, G.R. and Lasmanis J. 1952. Reservoirs of Micrococcus pyogenes in bovine mastitis. Am. J. Vet.Res. 13(49): 500-503.

Sumathi BR, Veeregowda BM, Amitha RG. Prevalence and antibiogram profile of bacterial isolates from clinical bovine mastitis. Vet World. 2008; 1(8):237-238.

Tenhagen BA, Hansen I, Reinecke A, Heuwieser W. Prevalence of pathogens in milk samples of dairy cows with clinical mastitis and in heifers at first parturition. $J$. of Dairy Research. 2009; 76:179-187.

Wang, S., C. Wu, J. Shen, Y. Wu and Y. Wang, 2013. Hypermutable Staphylococcus aureus strains present at high frequency in subclinical bovine mastitis isolates are associated with the development of antibiotic resistance. Vet. Microbiol., 165: 410-415.

Zutic M, Cirkovic I, Pavlovic L, Zutic J, Asanin J, Radanovic O et al.2012. Occurrence of methicillin-resistant Staphylococcus aureus in milk samples from Serbian cows with subclinical mastitis. Afr. J. Microbiol. Res. 6:5887-5889.

\section{How to cite this article:}

Rani Prameela, D., D. Sreenivasulu, N. Mangadevi and Karthik, A. 2020. Antimicrobial Susceptibility and Resistance Pattern of Mastitis Milk Samples from Chittoor District, Andhra Pradesh, India. Int.J.Curr.Microbiol.App.Sci. 9(07): 2831-2839. doi: https://doi.org/10.20546/ijcmas.2020.907.335 